sulph., and later by iodide of potassium. Recovered and regained $6 / 9$ of vision.

Vision now $6 / 9$ and $6 / 6$ partly.

Note the distinct partial post-neuritic atrophy of discs. Also note the remains of the "star figure" at the disc edge of the macula in each.

She has been in excellent health since and does well at school.

The powdery lead paint on the verandah railings and garden rails was replaced by zinc white.

\title{
THE OXFORD OPHTHALMOLOGICAL CONGRESS, 1922
}

The Thirteenth Annual Meeting of the Oxford Ophthalmological Congress was held at Oxford on July 6, 7, and 8 last.

As in past years the proceedings took place in the Department of Human Anatomy of the University Museum, kindly lent for the purpose by Professor Arthur Thomson, Professor of Human Anatomy, whilst Keble College was again available as headquarters through the courtesy of its Warden, the Reverend B. J. Kidd, D.D.

The meeting opened at 10.15 a.m. on Thursday, July 6 , and in the unavoidable absence of the Master, Mr. Sydney Stephenson, the Deputy-Master, Mr. P. H. Adams, of Oxford, occupied the Chair. In declaring the Congress open, Mr. Adams voiced the feelings of all present in expressing deep regret at the absence of the Master.

The discussion on "The Significance of Retinal Haemorrhages" followed, and was opened by Dr. C. O. Hawthorne (London) from the point of view of the physician, and by Mr. P. H. Adams from that of the ophthalmologist.

The two papers were followed with much interest, and the subject was discussed by the following :-Mr. Ernest Clarke (London), Dr. T. Harrison Butler (Leamington Spa), Dr. Lundsgaard (Copenhagen), Mr. R. Foster Moore (London), Dr. A. G. Gibson (Oxford), Mr. N. C. Ridley (Leicester), Mr. J. Jameson Evans (Birmingham), Mr. D. Leighton Davies (Cardiff), Miss Marion Gilchrist (Glasgow), Dr. Stobie (Oxford), Mr. Matheson Mackay (Hull), Dr. Thomson Henderson (Nottingham), Mr. John Hern (Darlington), Mr. B. Cridland (Wolverhampton), Mr. Traquair (Edinburgh), and Mr. J. Gray Clegg (Manchester).

At the conclusion of the discussion the Annual General Meeting was held, when a resolution of deep regret at the absence of the Master was unanimously passed, to whom a telegram to this effect was sent. 
The Hon. Secretary reported that the finances of the Congress were in a satisfactory state, and it had therefore been decided by the Council to make a second donation of ten guineas to the Illustration Fund of the Ophthalmological Society of the United Kingdom, that twenty-six new members had been elected during the year, and also that as the extension of the meeting to Saturday had proved so successful last year it had been repeated at the present meeting.

After lunch Mr. C. G. Russ Wood (Shrewsbury) read a paper on the comparafive value of artificial illuminants embodying some valuable original work by him on the subject, and Mr. T. Stewart Barrie (Glasgow) drew attention in a paper entitled "The spontaneous cure of strabismus convergens" to the diminution and not infrequently the disappearance of squint in children, as shown by statistics obtained in School Clinics between the ages of 5 and 14.

Discussion followed both papers.

The afternoon session concluded with a contribution by Mr. J. Gray Clegg (Manchester) in which he gaye his impressions of an International Congress of Ophthalmology, held in Washington, D.C., U.S.A., in April last, together with interesting experiences of various clinical centres in the United States and Canada. On Friday morning the Doyne Memorial Lecture was delivered by Dr. J. Burdon-Cooper, of Bath, the subject being, "The Aetiology of Cataract."

After a fitting tribute to the late Robert W. Doyne, Founder of the Congress, Dr. Burdon-Cooper reviewed the work already published by various authors on cataract, and then described his own research in this field upon which he has been engaged since 1906.

The Lecturer is to be congratulated upon a valuable contribution to the investigation of the causes of cataract in its various forms, and the address should be read with profit and interest by all ophthalmologists.

At its conclusion Dr. Burdon-Cooper received the Doyne Memorial Medal of the year.

Mr. A. L. Whitehead (Leeds) described some cases of eclipse amblyopia and their after history, and Mr. A. L. MacCallan, C.B.E. (Cairo), referred to the occurrence of trachoma of the lacrymal sac, whilst a paper on the dry sterilization of instruments by Dr. C. F. Bentzen (Copenhagen) concluded the morning session. After lunch members assembled at the Oxford Eye Hospital where Sir Anderson Critchett, Bt., K.C.V.O., opened a discussion on methods of operating for cataract.

Sir Anderson, in an extremely interesting address, reviewed the operations of the past, and referring to the various procedures 
in vogue at the present time, urged eclecticism in operating as being of the first importance. He had advised this as early as 1883 in a paper published in the British Medical Journal, and his subsequent experience up to the present time, strongly conformed this view.

Dr. Lundsgaard (Copenhagen) described a sub-conjunctival method of extracting cataract which he had found of good service in a number of cases.

Lieut.-Col. H. Smith, C.I.E., I.M.S., late of Amritsar, spoke on the intracapsular method as performed by Dr. Barraquer, of Barcelona, and discussed the subject in general.

Dr. T. 'Harrison Butler '(Leamington Spa), Mr. C. Killick (Bradford), and Mr. B. Cridland (Wolverhampton) referred to the value of cutting a bridge of conjunctiva in making the section, and gave their experience of cases. The subject was further discussed by Mr. E. E. Maddox (Bournemouth), Mr. Johnson Taylor (Norwich), and Mr. A. H. H. Sinclair (Edinburgh).

On Saturday morning papers were read by Mr. J. Gray Clegg (Manchester), on bilateral symmetrical congenital korectopia and melanosis of the eye, skin and palate, by Mr. A. S. Percival (Newcastle-on-Tyne) on (1) a note on light sense, (2) a neglected factor in the aetiology of coal-miners' nystagmus, by Mr. T. Harrison Butler on "Changes in Refraction," a contribution which met with free discussion, and by Mr. A. Greene (Norwich), who described a useful point in squint operations, and, secondly, a case of foreign body in the lens.

In the Scientific Museum Mr. J. H. Tomlinson (London) exhibited a transillumination lamp with a rheostat to run from the main, and some interesting pathological specimens were shown by Mr. R. J. Coulter (Newport), Mr. N. Pike (Cheltenham), and Mr. B. Cridland.

In the Commercial Museum a large collection of ophthalmic apparatus and instruments, etc., was on view.

On Thursday afternoon, at the close of the session, a garden party .was held at New College, where members and their friends were received by Professor Turner and the Hon. Mrs. E. F. Matheson.

The Annual Dinner took place in the evening in the Hall of Keble College.

The meeting was highly successful and well attended, and amongst members from overseas were Dr. Lundsgaard (Copenhagen), Professor Fritz Ask (Lund, Sweden), Dr. C. F. Bentzen (Copenhagen), and Dr. Saunte (Odense, Denmark). 